Tatiana Yudina, Dr. Sci. in Technical Sciences, Professor ORCID: 0000-0001-9863-878X ResearcherID: https://publons. com/researcher/N-4770-2016/

Olha Bezruchenko, postgraduate student Kyiv National University of Trade and Economics, 19, Kyoto str. Kyiv, 02156, Ukraine ORCID: 0000-0001-6397-8194

\title{
MANUFACTURING TECHNOLOGY OF A GLUTEN-FREE CHOCOLATE CAKE
}

The article deals with the manufacturing technology of a gluten-free chocolate cake, the expediency of using a mixture of gluten-free flour raw materials, milk protein buttermilk concentrate, cocoa powder in the developed production method.

Keywords: gluten-free chocolate cake, corn flour, rice flour, buttermilk concentrate.

Relevance of the research topic. Nowadays dietary nutrition is very important, considering the increasing number of genetic and allergic diseases. One of the diseases which requires nutrition correction is celiac disease, a chronic, genetically determined disease which is manifested in persistent gluten intolerance (cereal protein of wheat, rye, barley, oats) with the development of mucosa atrophy of the small intestinal and an associated malabsorption syndrome [1].

According to the Ukrainian Celiac Society 450,000 Ukrainians suffer from celiac disease each year. Most often celiac disease is diagnosed in children in the age group of six months to 2 years, who develop permanent gluten intolerance [2].

The only way to treat this disease and to prevent all its serious complications is to follow a strict and lifelong gluten-free diet. As for cereals, it is allowed to consume buckwheat, corn and rice.

But unfortunately, in Ukraine the production of gluten-free products is not adjusted, the range of gluten-free flour confectionery is supplied mainly by imported products, which have a fairly high price.

Therefore, manufacturing technology and the introduction of gluten-free pastry in the domestic market under conditions of resource-saving state policy, accompanied by the increased focus of domestic enterprises to manufacture import-substitute products currently generate a significant challenge. 
Formulation of the problem. Cakes account for about $15 \%$ of the gross output in terms of the overall flour confectionery (FC) market structure. These products are pleasant to the sight and taste; they digest well by the human body and therefore are popular with the population.

However, nutritional composition analysis of cakes indicates their low biological value on account of insignificant content of proteins, polyunsaturated fatty acids, macro- and microelements. Moreover, cakes are a major source of gluten, since they include wheat flour as a major raw material resource. Therefore, the main challenge is to develop innovative manufacturing technologies and expand the range of gluten-free cakes with high biological value and specified consumer attributes.

Analysis of recent research and publications. The scientific literature overview has showed that gluten-free products are manufactured by various hydrocolloid-based mixtures which integrally add the necessary processing attributes to the dough and ensure the quality of finished products.

According to the research findings [3], the production of flour products, in particular gingerbread, involves the use of a mixture of various hydrocolloids. Their combination adds the desired processing properties to the dough and insures the quality of finished products. More specifically, potato starch, soy protein isolate and natural polysaccharide have been studied.

A group of researchers guided by V. Dorokhovich developed manufacturing technologies of special-purpose flour confectionery (cookies, cakes, biscuits) using gluten-free flour - rice, corn, and buckwheat. To increase the nutritional and biological value of flour products for patients with celiac disease, the scientists used soy and nut flour supplements, as well as malt flour, soybeans and peas. The researchers of the National University of Food Technologies developed production methods for cookies, cakes, biscuits using gluten-free flour and sugar substitutes - lactitol, isomalt, and fructose [4].

There are several studies [5-7] intended to identify optimal proportions of structure-forming components for flour confectionery manufactured from rice flour, extruded corn flour and gluten-free starchy protein mixtures. It is proved that the use of different proportions of protein and starch can be used to adjust the specified attributes of flour confectionery in terms of the production method and the manufacturer's requirements.

The available domestic and foreign publications lack information about the methods of producing gluten-free cakes based on buttermilk concentrate. Therefore, the purpose of the research is to develop a manufacturing technology for a chocolate gluten-free cake using milk protein concentrate, which will broaden the range of gluten-free confectionery of high nutritional value. 
Presenting main material. It is proved that the use of gluten-free flour in the production of flour confectionery, in particular cakes containing chemical baking powder, challenges the manufacturing technology and requires various agents to refine the structure of gluten-free dough [8].

Several measures to regulate the structural and mechanical attributes of glutenfree dough have been determined. Firstly, it is the use of flour mixtures, rather than certain types of gluten-free flour, which can significantly enhance the nutritional and biological value, the structure of products, expand the raw material base and the range of finished products. Secondly, it is a meaningful increase in the nutritional value of gluten-free flour confectionery by adding protein-containing raw materials, in particular, milk protein concentrates, to the recipe [9].

The manufacturing technology of a chocolate gluten-free cake based on milk protein concentrate has been accomplished on account of a range of previous experiments along with scientific and technical research findings.

The developed production methods suggest the following ingredients: flour, sugar, butter, milk protein component, melange, ammonium bicarbonate, and sodium bicarbonate.

Corn and rice flour are used as flour, milk protein concentrate buttermilk (MPCB) is used as a milk component, cocoa powder is added subsequently.

Milk protein concentrate is obtained from raw milk by settling out of casein and whey proteins. It has a much higher biological value than dairy cheese since whey proteins have an advantage over casein fractions in the content of essential amino acids. The increased nutritional value of milk protein concentrate buttermilk is accounted for $20.8 \%$ of protein, $1.34 \%$ of fat, $0.16 \%$ of calcium, $0.24 \%$ of phosphorus, trace elements and water-soluble vitamins [10].

Adding cocoa powder to the recipe enriches the product with vitamins (A, E, PP, groups B), beta-carotene and minerals [11].

The comprehensive study has made it possible to substantiate the recipe composition of the chocolate gluten-free cake. The recipe components are taken in the following proportions, wt. \%: rice flour $-4.4 \ldots 7.8$; corn flour $-0.3 \ldots 10.4$; cocoa powder -5.1 to 7.8 ; sugar $-26,4 \ldots 28,1$; butter $-11.03 \ldots 12.66$; MPCB $-25.2 \ldots$ 28.1 ; melange $-10.2 \ldots 13.03$; ammonium bicarbonate $-0.07 \ldots 0.09$; sodium bicarbonate $-0.05 \ldots 0.07$.

The method of obtaining a new flour confectionery product - a gluten-free chocolate cake is as follows: whisk softened butter and sugar for (10.. 15) $60 \mathrm{~s}$, combine with buttermilk milk protein concentrate and continue whisking until smooth. Once this is done, add melange, sodium bicarbonate, ammonium bicarbonate, thereupon mix thoroughly, pour the mixture of corn and rice flour, cocoa powder and knead the dough for $(3 \ldots 5) 60$ seconds. The dough is then laid out into ready-made moulds and baked at $160 \ldots 170 \mathrm{C}$ for $(25 \ldots 30) 60$ seconds. 
The fabricated product looks appealing. It has a buckled, crack-free top, a dense dark brown soft part with a Cheesecake -like texture [12].

Conclusions. The expediency of manufacturing gluten-free chocolate cakes from corn and rice flour, milk protein concentrate, cocoa powder is substantiated in the research. The proposed manufacturing technology of gluten-free chocolate cake with the use of milk protein buttermilk concentrate enables us to expand the range of gluten-free flour confectionery with high nutritional value.

\section{REFERENCES}

1. Jeffrey L. Gluten-free baked products / L. C. Jeffrey, W. A. Atwell // AACC International, Inc., 2014. 88p.

2. Gorobec A. O. Osoblivosti harchuvannya ditej pri celiakiyi A. O. Gorobec // Medicina transportu Ukrayini. - 2015. - № 3-4. - S. 45-50.

3. Barsukova N. V. Razrabotka tehnologii pryanichnyh izdelij na osnove bezglyutenovogo muchnogo syrya: avtoref. dis. . na soiskanie uchenoj stepeni kand. tehn. nauk: 05. 18. 15. S-P., 2005. $20 \mathrm{~s}$.

4. Dorohovich V. V. Naukove obgruntuvannya ta rozroblennya tehnologij boroshnyanih konditerskih virobiv specialnogo diyetichnogo priznachennya: avtoref. dis...na zdobuttya nauk. Stupenya doktora. tehn. nauk: 05. 18. 16. Kyiv, 2010. 39 s.

5. Renzyaeva T. V., Bakirova M. E. Pechene iz risovoj muki dlya specializirovanogo pitaniya. Tehnologii pishevoj I pererabatyvayushej promyshlenosti APK-produkty zdorovogo pitaniya. 2017. № 1. S. 49-54.

6. Camino M., Mancebo Patricia Rodriguez, Manuel Gomez Assessing rice flour-starch-protein mixtures to produce gluten free sugar-snap cookies. LWT-Food Scienc and Technology. 2016, Volume 67. P. 127-132.

7. Tetiana Lisovska, Olga Rybak, MykolaKuhtyn, Nina Chorna. Investigation of water binding in spongecake with extruded corn meal // Ukrainian Food Journal, 2015. Vol. 4. Is. 3. P. 413-422.

8. Drobot V. I. Tehnologichni aspekti vikoristannya boroshna krup'yanih kultur u tehnologiyi bezglyutenovogo hliba / V. I. Drobot, A. M. Grishenko // Obladnannya ta tehnologiyi harchovih virobnictv: temat. zb. nauk. pr. / Donec. nac. un-t ekonomik I itorgivli im. M. Tugan-Baranovskogo, 2013. Vip. 30. S. 52-58.

9. Yudina T. I., Bezruchenko O. M., Pavlyuchenko V. O. Obgruntuvannya skladu boroshnyanoyi sirovini u tehnologiyi bezglyutenovih keksiv. Praci Tavrijskogo derzhavnogo agrotehnologichnogo universitetu. TDATU. Melitopol: TDATU, 2019. Vip. 19, t. 1. S. 179-186.

10. Gnitsevich, V. Yudina, T., Deynichenko L. (2016) Tekhnolohiya ta biolohichna tsinnist molochno-bilkovykh kopretsypitativ [Technology and biological value of milk-protein coprecipitates] Goods and markets. - № 2. - P. 148-157. Retrieved from: http://nbuv. gov. ua/UJRN/tovary_2016_2_19. [in Ukrainian].

11. Konditerske I hlibopekarne virobnictvo [Electronic resource] - http://www. breadbranch. com/magazine/latestnumber. html

12. Zbirnik receptur boroshnyanih konditerskih i zdobnih bulochnih virobiv: Navchalno-praktichnij posibnik / O. V. Pavlov. - Vidannya pereroblene i dopovnene. Kiyiv: ProfKniga, 2018. - 336 s. 